\title{
Confronting the gauntlet: understanding incidental capture of green turtles through fine-scale movement studies
}

\author{
Catherine M. McClellan*, Andrew J. Read \\ Division of Marine Science and Conservation, Duke University Marine Laboratory, 135 Duke Marine Lab Road, \\ Beaufort, North Carolina 28516, USA
}

\begin{abstract}
We conducted a 2 yr study of small juvenile green sea turtles Chelonia mydas in an estuary in North Carolina, USA, to examine how turtle behavior affected their vulnerability to incidental capture in an artisanal gill net fishery. We used sonic and satellite telemetry to track the movements and habitat use of 10 green turtles during the summers of 2005 and 2006. Individual turtles established summer foraging sites and showed very strong fidelity to particular tidal creeks and marsh islands. Turtles were strongly associated with seagrass habitat and were easily disturbed by natural and anthropogenic activity. We found that green turtles and gill net fishers exhibited similar habitat preferences, leading to the potential for entanglement, a finding corroborated by $8 \mathrm{yr}$ of by-catch records. Individual turtles interacted with multiple gears during our study as a result of fishing activity in their small home ranges.
\end{abstract}

KEY WORDS: By-catch $\cdot$ Gill nets $\cdot$ Telemetry $\cdot$ Sea turtles

Resale or republication not permitted without written consent of the publisher

\section{INTRODUCTION}

The by-catch of protected species, including marine birds, mammals and turtles, is a significant conservation issue for some fisheries. Sea turtles, protected in US waters under the 1973 Endangered Species Act (ESA), are particularly vulnerable to incidental capture in fishing gear (Crouse et al. 1987, Epperly et al. 1995, Lewison et al. 2004, Peckham et al. 2007). In some cases, time-area restrictions of fishing effort are the most effective means of reducing or eliminating the threat of by-catch (Young 2001). For example, the bycatch of loggerhead Caretta caretta and Kemp's ridley Lepidochelys kempii turtles resulted in the seasonal closure of a gill net fishery in Pamlico Sound, North Carolina (Santora 2003, McClellan et al. 2009). However, the by-catch of green sea turtles Chelonia mydas persists in the shallow water areas that remain legally open to fishing under a Section 10 permit (McClellan et al. 2009).
Juvenile green turtles forage on seagrass in the sounds of North Carolina during summer and autumn (May to November) (Epperly et al. 1995, 2007). This is their primary diet item in neritic habitats along the coasts of the western Atlantic (Bjorndal 1980, Mendonça 1983). Gill net fishers operate a variety of gear (large and small mesh, sink and float set nets, run around nets, drift nets) throughout North Carolina sounds in all seasons, targeting a variety of fish species (Steve et al. 2001). The large mesh (>11 cm) bottom-set sink gill net has been identified as a primary concern with respect to sea turtle by-catch (STAC 2006), particularly in the deepwater areas of Pamlico Sound (Santora 2003, McClellan et al. 2009). Since 2000, the North Carolina Division of Marine Fisheries (DMF) has held a Section 10 ESA permit to authorize Pamlico Sound's autumn flounder fishery (September to December) under a set of restrictions designed to reduce the frequency of sea turtle by-catch. The permit allows the fishery to operate unattended in shallow water areas, 
provided that the by-catch does not exceed speciesspecific limits. A variety of management measures were implemented in 2000 (Santora 2003); however, in 2002 the National Marine Fisheries Service (NMFS) permanently closed the deepwater portion of the fishery due to persistent by-catch, mostly of loggerhead and Kemp's ridley turtles (NMFS 2002, 67 FR 56,931, September 6, 2002). The fishery is now restricted to shallow water areas of the sound (see Fig. 1). Chelonia mydas is the species caught most frequently in the remaining open fishing areas. Most turtle by-catch occurs in areas of high fishing effort along the sound side of the Outer Banks.

In the Caribbean, green turtles maintain gardens of seagrass, exhibit extreme site fidelity, and enrich the nutrient content of vegetation through grazing (Bjorndal 1980). There are striking exceptions to this association with seagrass in the literature, however, as post-pelagic green turtles have been documented as having a variety of algae and invertebrates in their diet (reviewed in Bjorndal 1997). Therefore, we were interested in studying the relationship between green turtles and seagrass meadows in North Carolina and determining whether or not this relationship could inform us about their vulnerability to by-catch in shallow-water gill net fisheries. In particular, we examined the habitat preferences and behavior of green turtles which could increase their risk of incidental capture in fisheries.

\section{MATERIALS AND METHODS}

Study area. Our study was conducted in a North Carolina estuary $\left(35^{\circ} \mathrm{N}, 76^{\circ} \mathrm{W}\right)$ consisting of a series of shallow coastal lagoons separated from the Atlantic Ocean by barrier islands (Fig. 1). We focused on 2 shallow water regions - Core/Back Sound $\left(373 \mathrm{~km}^{2}\right)$ and the Outer Banks portion of the Pamlico Sound Gill Net Restricted Area (PSGNRA) $\left(712 \mathrm{~km}^{2}\right)$ (Fig. 1). Green sea turtles are seasonal (April to December) residents of these waters (Epperly et al. 1995, 2007). Large-mesh (14 to $18 \mathrm{~cm}$ stretch mesh) gill nets are fished in both areas throughout the year.

Seagrass beds are common inside the chain of barrier islands that delimit North Carolina's lagoonal estuaries (Ferguson et al. 1993). The distribution of seagrass is limited by several factors, including light, depth, current velocities, shifting sediments, and nutrient runoff from the land (Ferguson et al. 1980, Fonseca et al. 1983, Thayer et al. 1984). In North Carolina, seagrasses primarily include eelgrass Zostera marina and shoalgrass Halodule wrightii (Thayer et al. 1984). Seagrass meadows occur in homogeneous or mixed stands, dominated by Zostera in the winter and spring, which then dies off in the heat of the summer and gives way to Halodule (Thayer et al. 1984). Green turtles have been documented to feed on these genera in several parts of the world (reviewed in Bjorndal 1997). Meadows of seagrass vary in size from small isolated patches to continuous expanses, both of which can be exposed during portions of the tidal cycle (Thayer et al. 1984). These meadows are important habitat, structure, and/or food for many marine organisms (Thayer et al. 1984, Joseph et al. 2006).

Field sampling. We relied on the help of commercial pound net, long haul seine, and gill net fishermen to collect green turtles during the months May to October of 2005 and 2006. We arranged trips to accompany fishers during normal fishing operations in areas where green turtle by-catch has been documented; most notably in the sound area behind Cape Hatteras (Fig. 1). However, few fishers were operating in this region during the summer months (May to August) and we collected only 1 green turtle in 2005. Our effort consisted of 1 gill net and 3 pound net trips with commercial fishers, and $7 \mathrm{~d}$ of gill netting on our own. In 2006, we expanded our capture area to Core Sound and Back Sound. After 8 long haul seine and 21 pound net trips, we were able to collect the remaining 9 turtles in this study. Most turtles in 2006 were collected in conjunction with trips observed by National Marine Fisheries Service (NMFS) biologists; all turtles, with one exception (2005), were brought back to the Duke Marine Laboratory.

We processed each turtle according to standard NMFS techniques (NMFS SEFSC 2008). This entailed measuring the straight (SCL) and curved carapace lengths (CCL) and widths of each turtle, weighing them with a Pelosa ${ }^{\circledR}$ macro-spring scale, drawing a $5 \mathrm{ml}$ blood sample from the dorsal cervical sinus, and collecting a $3 \mathrm{~mm}$ skin biopsy from a rear flipper. We also applied INCONEL Style 681 tags (National Band and Tag Co.) to each rear flipper and a $125 \mathrm{KHz}$ unencrypted Passive Integrated Transponder (PIT; Destron-Fearing Corporation) to the front left flipper. We attached a satellite transmitter (SPOT5, Wildlife Computers) and an ultrasonic transmitter (CHP-87-S, Sonotronics) to the carapace of each turtle using a cool-setting 2-part epoxy (PowerFast $\left.{ }^{\circledR}\right)$ (NMFS SEFSC 2008). The total weight of both transmitters and epoxy did not exceed $5 \%$ of the turtle's body weight. We minimized the epoxy footprint due to the small size of the turtles in our study. Transmitters are loosened and shed with pealing scutes as the turtles grow; retention can vary significantly throughout the year (i.e. the rapid growth seasons spring and summer risk shorter tag retention than the slower growth seasons autumn and winter).

Ultrasonic acoustic (hereafter 'sonic') transmitters emit a sound at regular intervals and may be detected underwater with the aid of a directional hydrophone and re- 


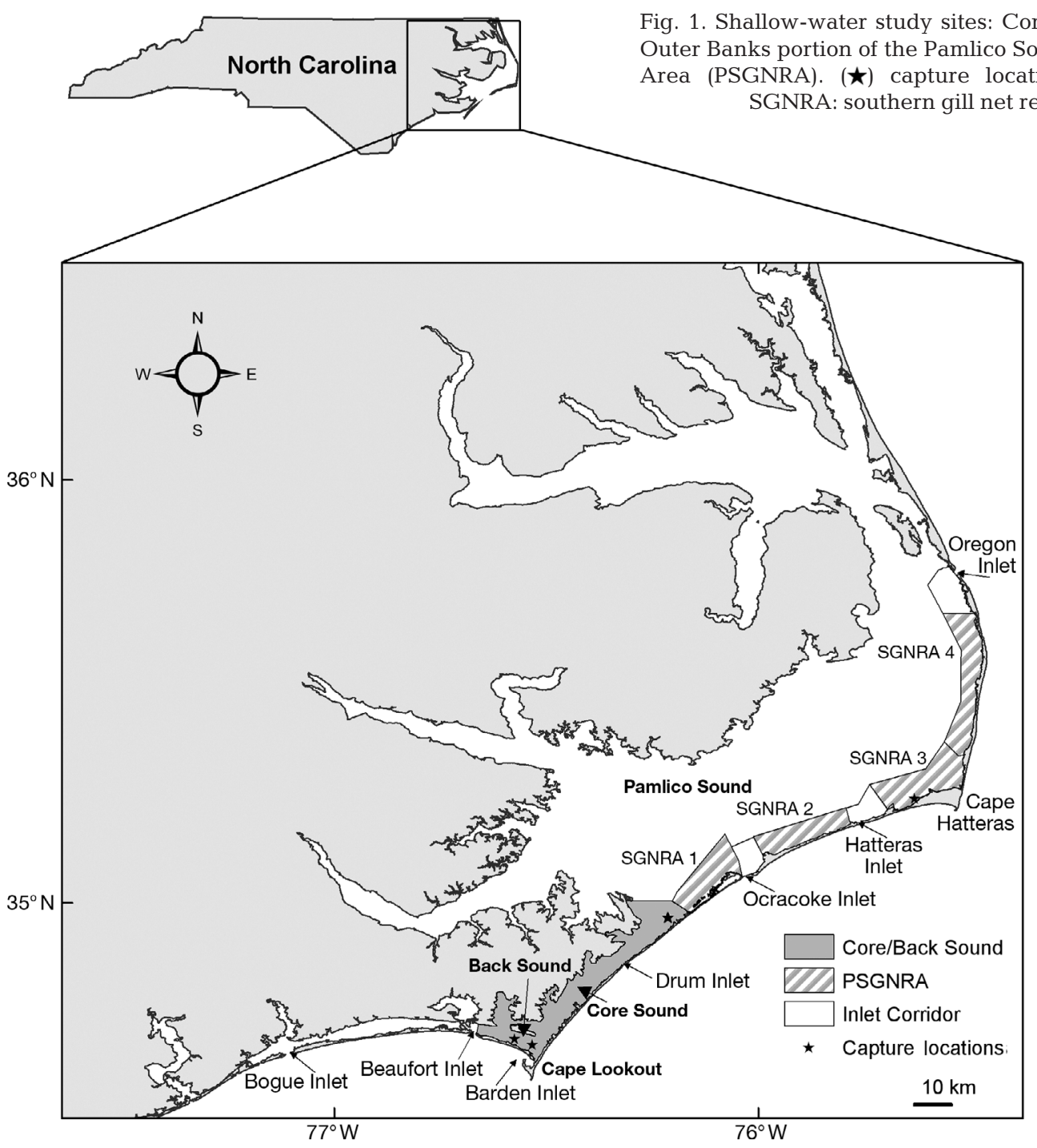

ceiver. Individual tags are identified by unique codes according to signals at different frequencies and intervals. We used frequencies from 70 to $80 \mathrm{kHz}$, well above the auditory capabilities of green sea turtles (200 to $700 \mathrm{~Hz}$ ) (Bartol \& Musick 2003). The manufacturer estimated a detectable range for our transmitters at $3+\mathrm{km}$, but our field testing yielded ranges of only $800 \mathrm{~m}$ in deep open water, $500 \mathrm{~m}$ in shallow open water, and $<100 \mathrm{~m}$ near seagrass beds and sandbars.

We held the animals overnight in flow-through sea water tanks and released them the following day, either in the SGNRA 3 in the PSGNRA study site (2005) or at the southern end of Core/Back Sound study site (2006) at a maximum of $42 \mathrm{~km}$ from their capture location (minimum $4 \mathrm{~km}$ ). We tracked turtles by hydrophone for as long as possible on the day of release. The direction of the strongest signal was followed until the received signal was equally strong in all directions, indicating that we were in close proximity to the tagged turtle, and recorded these coordinates as the turtle's location.

After release, we conducted daily surveys of the study areas to relocate tagged animals. If we did not find an animal, we executed an extensive search in a grid pattern at $100 \mathrm{~m}$ intervals as long as daylight and weather conditions permitted. When an animal was located, we recorded water depth, water temperature, whether or not seagrass was present, notes on signal strength, and whether or not we were able to see the turtle. We typically observed turtles from a distance and waited for the animal to surface, or took one location record and moved on to search for other animals. We estimated our sonic location error in the field at each location, based on signal strength, tracking conditions, and visual observation. Our mean, median, and range of estimated error for our best locations per day (i.e. those used in habitat analyses) was $32 \mathrm{~m}, 0 \mathrm{~m}$, 
and 0 to $650 \mathrm{~m}$, respectively. If we were able to visually relocate the turtle, we noted the turtle's appearance and behavior. We also documented the location and approximate length of any large-mesh gill nets that we found opportunistically during our surveys.

The satellite transmitters recorded daily water temperature histories experienced by the turtles in userdefined bins $\left(2^{\circ} \mathrm{C}\right)$ and were programmed with a continuous duty cycle (i.e. to function continuously in air). Location and water temperature data were uplinked to satellites when the turtles surfaced to breathe. We received daily updates from each transmitting turtle.

We converted and de-coded satellite-linked positional data using SatPak software (Wildlife Computers) and imported these data into a geographic information system (GIS) for movement analysis. Satellite location data have potentially large errors (Hays et al. 2001, Vincent et al. 2002), so we filtered all the data to remove implausible locations using a 3-stage algorithm parameterized with biologically appropriate speed and distance thresholds (McConnell et al. 1992, Austin et al. 2003).

We reconstructed sea turtle movements by plotting the best received location per day (based on Argos location quality classifications) of the filtered location data in an Albers Equal Area projection and created poly-lines between points in ArcView 3.2 (ESRI 1999) with Animal Movement Extension (Hooge \& Eichenlaub 2000). The location error structure of satellite data is complicated and generally not reported in absolute terms (Vincent et al. 2002). However, based on the empirical location-class specific deviations from true reported in Hays et al. (2001) and the distribution of location classes received during our study, our satellite data have an estimated mean, median, and range error of $3 \mathrm{~km}, 1 \mathrm{~km}$, and 0.01 to $10 \mathrm{~km}$ respectively. The data filtration process we employed (previous paragraph) serves to minimize these errors by removing those locations which are implausible. We estimated distance traveled in ArcInfo (ESRI 2006, ArcGIS 9.2). We summarized the area of habitat use for each turtle by constructing fixed kernel utilization distributions (UDs) from telemetry positions by season. We restricted the habitat analyses to the summer months (May to August), when turtles had established foraging sites, in order to avoid biases induced by behavioral changes induced by seasons. UDs were calculated in ArcGIS with Hawth's Tools (Beyer 2004) with a fixed ad hoc smoothing factor of $\mathrm{H}=2000$ (units in meters) using all filtered locations for each turtle. When faced with the trade-off between sample size and serial autocorrelation in calculating UDs, we sided with sample size as it is more important than independence in estimating home ranges (Kernohan et al. 2001). UDs are nonparametric analyses which do not require indepen- dence, and reducing data to independent locations to avoid serial autocorrelation has been criticized for its removal of important biological information from an animal's movements (de Solla et al. 1999). Our selection of a fixed $2 \mathrm{~km}$ bandwidth was optimal for the aquatic turtles in our study area (Silverman 1986). UD area was corrected by clipping out portions that encompassed any land, and we used the 95th percentile density contour values for consistency with other studies (Laver \& Kelly 2008). We recognize that the UD estimates do not represent the turtles' true home ranges (Worton 1989), but rather their summertime habitat use within a 2 to 5 wk period. Preliminary asymptote analysis (Laver \& Kelly 2008) of cumulative core UDs (50th percentile density contour) calculated at daily intervals suggested that a minimum sample period of $4 \mathrm{~d}$ was necessary to estimate a UD for turtles in the present study.

Fisheries data. We obtained coordinates for the boundaries of the PSGNRA for each year from DMF Proclamations (Proclamations M-8-2005, 3 August 2005; M-9-2006, 11 August 2006; North Carolina Division of Marine Fisheries 2005-2007) (Fig. 1). DMF observes approximately $10 \%$ of the autumn flounder gill net fishing trips (based on log book reports of effort) in the PSGNRA between 1 September and 15 December each year (Price 2006, 2007a). DMF also observes a small number of trips in other regions and times (Price 2007b). We obtained gill net fishing effort data (2005 and 2006) and sea turtle by-catch records (2000 to 2007) from DMF to evaluate the distribution and habitat characteristics of the shallow water fishery and to assess the spatial distribution of overlap between green turtle habitat use and gill net fishing effort.

Habitat analyses. We used 3 variables to evaluate habitat selection: water depth, distance to seagrass beds, and distance to shore. We obtained a bathymetric digital elevation model (DEM) at $30 \mathrm{~m}$ resolution from the National Oceanic and Atmospheric Administration's National Ocean Service (NOAA-NOS Special Projects Office 1998) to identify (mean low) water depths (1 $\mathrm{m}$ resolution) used by turtles and fishermen with gill nets. We also recorded water depth and temperature $\left( \pm 0.1^{\circ} \mathrm{C}\right)$ where turtles were tracked with sonic telemetry in the field using a Garmin 250C depth finder.

We obtained digitized polygons of seagrass beds interpreted from aerial photography (scale 1:20 000 to 1:50 000) from the NOAA-NOS Applied Spatial Ecology and Habitat Characterization Division. The polygons represent a mosaic of aerial surveys conducted in 1985, 1988, 1991, and 1992 (Ferguson et al. 1993). These surveys have demonstrated that seagrass meadows in our study site are relatively stable through time (Ferguson \& Korfmacher 1997). We used point loca- 
tions of seagrass beds recorded during tracking to assess the accuracy of these polygons at the time of the study. Assessment of seagrass polygons with in situ observations showed that 3/164 records were misclassified as seagrass when the bottom was sand (error of commission), whereas 11/164 records were misclassified as not being seagrass when seagrass was present (error of omission). The true nature of seagrass patches in the field cannot be captured by the GIS polygons, but the misclassification was low and the polygons generally represented the spatial extent of seagrass in this area quite well. The shoreline we used in our analysis was NOAA's Medium Resolution Digital Vector US Shoreline (scale 1:70000). We created distance layers in GIS for seagrass and shoreline to $100 \mathrm{~m}$ resolution using the Euclidean Distance function in ArcInfo (ESRI 2006, ArcGIS 9.2).

We defined habitat availability at 2 spatial scales proposed by Johnson (1980); second-order habitat selection occurs within the study site while third-order selection occurs within the animal's UD. In each case, the individual turtle was our experimental unit. Identity of gill net fishers, however, was confidential, and we could not generate UDs for individual fishers. Comparisons between green turtles and gill net fishers' sets were therefore restricted to second-order selection comparisons.

To characterize available habitat at the study site scale, we generated 250 random points in ArcGIS using Hawth's Tools (Beyer 2004) in each study region (Core/Back Sound and PSGNRA) for a total of 500 points over an area of $1125 \mathrm{~km}^{2}$. We assume that these random points represent the habitat available in the study site based on accumulation curves of increasing sample size. Within the UD scale, we generated 50 random points in each turtle's unique UD. We sampled the locations of sea turtles (best per day), gill nets, and random points in GIS for our 3 habitat metrics (see above) in ArcGIS using Marine Geospatial Ecology Tools (Roberts et al. 2009).

We tested the null hypothesis that turtles use habitat randomly (i.e. no selection) with a Euclidean distance approach, treating water depth also as a distance category. For each animal we created vectors of mean use/mean availability ratios for each habitat metric (depth and distance to features) (see Conner \& Plowman 2001). We then used a multivariate analysis of variance (MANOVA) to determine if the overall mean vector ( $\left.\rho_{\text {habitat }}\right)$ significantly differed from a vector of $1 \mathrm{~s}$ (i.e. if significant, then selection). Univariate $t$-tests were used to determine which habitat types (if any) were used disproportionally. MANOVAs and $t$-tests were performed in SAS 9.1 (SAS Institute, 2003).

We also calculated the proportion of use for each habitat type for turtles, gill net sets, and random points.
The proportion of habitat available (random points) was subtracted from the proportion of use (turtles and fishers' nets) to assess habitat preference (positive values) (Johnson 1980). We assumed that the turtles could use all areas in our study region. We also assumed that the sample of gill nets observed represents the true distribution of fishing effort and that fishing could take place and be observed anywhere within the study site. We used raster calculation in ArcGIS to extract preferred habitat type (bathymetry, distance to shore, and distance to seagrass) from available habitat surfaces. We also used raster calculation to produce composite habitat preference grids for turtles and gill net fishers and to identify areas of overlap where conflict is likely to occur.

\section{RESULTS}

\section{Telemetry in the sounds}

We collected 1 green turtle in August 2005 from the PSGNRA region and 9 turtles between May and October 2006 from the Core/Back Sound region (Fig. 1).We worked with 8 fishers from the pound net, gill net, and long haul seine communities. The 2005 turtle was incidentally captured with hook and line by a recreational fisher.

Turtles ranged in size from 27.9 to $42.5 \mathrm{~cm}$ SCL (Table 1), typical for green turtles in North Carolina estuaries (Epperly et al. 1995, 2007). Eight turtles were tracked with both sonic and satellite telemetry, and 2 other individuals produced satellite locations only because of the turtles' immediate departure from the estuary (Table 1). Of the sonic locations, $37 \%$ were confirmed with visual observation of the turtles. The duration of satellite tracks ranged from 17 to $154 \mathrm{~d}$, with net distances traveled ranging from 9 to $1558 \mathrm{~km}$ (Table 1). Sonic tracks lasted from 0 to $74 \mathrm{~d}$, with net distances traveled ranging from 2 to $11 \mathrm{~km}$. Turtles occurred from Bogue Sound to Pamlico Sound, with the greatest concentration of records in Back Sound (Fig. 2). In general, each turtle used a very restricted area and showed little movement during the summer, followed by increased movement rates during the autumn, consistent with an onset of migratory behavior (Fig. 3). Mean ( $\pm 1 \mathrm{SD}$ ) summertime UDs for green turtles were $39.7 \mathrm{~km}^{2}$ (12.3), based on sonic tracking, and $84.6 \mathrm{~km}^{2}$ (48.3), based on satellite tracking (Table 2). UDs derived from satellite tracking encompassed the UDs obtained from sonic tracking and characterized the general area occupied by the turtles.

Sonic tracking was particularly difficult because aquatic vegetation and sand bars baffled the signal, reducing detectability and causing signals to bounce. 
Table 1. Chelonia mydas. Summary of green turtle telemetry tracking from North Carolina estuaries in 2005 and 2006 . Turtle E died within 1 mo post-release of its incidental capture in a large-mesh gill net during our study (see 'Results: Telemetry in the sounds' for details). SCL: straight carapace length; NA: not applicable

\begin{tabular}{|c|c|c|c|c|c|c|c|}
\hline \multirow{2}{*}{$\begin{array}{l}\text { Turtle } \\
\text { ID }\end{array}$} & \multirow{2}{*}{$\begin{array}{l}\text { Size }(\mathrm{cm}) \\
\quad \text { SCL }\end{array}$} & \multirow{2}{*}{$\begin{array}{l}\text { Date deployed } \\
\text { (d/mo/yr) }\end{array}$} & \multicolumn{2}{|c|}{ Release location } & \multirow[b]{2}{*}{$\begin{array}{c}\text { Track } \\
\text { duration (d) }\end{array}$} & \multirow{2}{*}{$\begin{array}{l}\text { Satellite/sonic } \\
\text { Net distance } \\
\text { traveled }(\mathrm{km})\end{array}$} & \multirow[b]{2}{*}{$\begin{array}{l}\text { Locations } \\
\text { (N) }\end{array}$} \\
\hline & & & $\begin{array}{c}\text { Latitude } \\
{ }^{\circ} \mathrm{N}\end{array}$ & $\begin{array}{c}\text { Longitude } \\
{ }^{\circ} \mathrm{W}\end{array}$ & & & \\
\hline A & 27.9 & 4/8/2005 & 35.22648 & 75.66933 & $65 / 12$ & $207 / 3$ & $38 / 27$ \\
\hline B & 33.5 & $23 / 5 / 2006$ & 34.69604 & 76.52854 & $36 / 74$ & $21 / 5$ & $11 / 13$ \\
\hline $\mathrm{C}$ & 29.8 & $23 / 5 / 2006$ & 34.69604 & 76.52859 & $33 / 9$ & $9 / 8$ & $7 / 8$ \\
\hline $\mathrm{D}$ & 32.7 & 5/6/2006 & 34.69503 & 76.52773 & $71 / 26$ & $246 / 11$ & $159 / 30$ \\
\hline $\mathrm{E}$ & 32.6 & 6/6/2006 & 34.69553 & 76.52746 & $60 / 60$ & 17/6 & $34 / 24$ \\
\hline $\mathrm{F}$ & 30.9 & $12 / 6 / 2006$ & 34.69566 & 76.52759 & $154 / 54$ & $158 / 4$ & $232 / 32$ \\
\hline $\mathrm{G}$ & 31.1 & $28 / 7 / 2006$ & 34.68428 & 76.52629 & $17 / 18$ & $20 / 2$ & 93/18 \\
\hline $\mathrm{H}$ & 42.5 & $16 / 8 / 2006$ & 34.67284 & 76.54298 & 75/8 & $117 / 2$ & $143 / 12$ \\
\hline I & 31.6 & $6 / 10 / 2006$ & 34.68428 & 76.52629 & 137/NA & $1558 / \mathrm{NA}$ & $347 / 0$ \\
\hline $\mathrm{J}$ & 28.4 & $6 / 10 / 2006$ & 34.68428 & 76.52629 & 29/NA & 90/NA & $36 / 0$ \\
\hline
\end{tabular}

Noise from boat traffic, wind and waves, and occasional dolphin echolocation exacerbated these problems. When animals settled into a foraging site, we obtained relatively few satellite uplinks, typically of poor location class. Our visual observations of tagged turtles indicated that the animals raised only their heads out of the water to breathe, not surfacing high enough to trigger activation of the saltwater switch on the transmitter, located on their carapace. This behavior precluded systematic comparisons of satellite and sonic locations. Tracking durations were short compared to our experience in the autumn (September to December) months (McClellan \& Read 2007). Water clarity varied throughout the summer, but on 17 occasions we were able to watch turtles underwater.

Turtles were disturbed by the presence of motorized vessels and often moved short distances upon our approach. Disturbance was also related to weather events, fishing activity or curious loggerhead turtles that we twice observed approaching and circling the green turtle that we were tracking. The degree of displacement appeared to be related to the nature of disturbance. When animals moved great distances, they were difficult to find with sonic methods.

We relocated all turtles either in or adjacent to seagrass. On 1 occasion we were able to witness a turtle foraging on Halodule wrightii. Five animals (Turtles $\mathrm{C}$, D, E, F, J) occupied tidal creeks, 2 set up residence along marshy shorelines (Turtle A) or marsh islands (Turtle B), and 2 inhabited seagrass beds in open water (Turtles G, H) (Fig. 2). The last 2 animals were observed in water approximately $4 \mathrm{~m}$ deep; the others were consistently found in water $<1 \mathrm{~m}$ deep and typically within a few meters from the shore (Table 2). In mid-summer, turtles were found in waters exceeding $28^{\circ} \mathrm{C}$. Two turtles moved regularly with the tide. Turtle E traveled in and out of a creek with the flood and ebb tide, while Turtle B swam around a marsh island relative to the tide.

Six animals initially established residence relatively near their release location, 2 moved northward up Core Sound, and 2 left the estuary immediately via Barden's Inlet (Fig. 2). The last 2 animals were released late in the field season (October), although both later re-entered the estuary.

Three of 10 turtles were subsequently re-captured in fishing gear after release: one in a gill net, one in a long haul seine, and one in a pound net. It is important to note that all turtles were initially captured in fishing gear, so these re-captures represent multiple occurrences of by-catch within a single season. The turtle caught in a gill net (Turtle E) was released alive, but confirmed dead 1 mo later when we recovered its bones and transmitters from the sea floor. The turtle caught in the long haul seine (Turtle B) had lost both of its transmitters, but was in good condition. This animal had grown $2.6 \mathrm{~cm}$ in $3.5 \mathrm{mo}$. We did not examine the turtle re-captured in the pound net (Turtle H), as the satellite tag was retrieved (11 wk after deployment) but the turtle was not present. Three of the sonic transmitters were found on the sea floor several weeks after deployment (that from Turtle B in Week 10, from Turtle F in Week 8, and from Turtle H in Week 3), presumably due to rapid growth spreading the scutes

Fig. 2. Chelonia mydas. Ten green turtles tracked during this study. Individual identities (Turtles A to J) are marked in the lower right-hand corner of each panel. Open circles indicate best daily locations derived from satellite telemetry; filled circles are best daily locations from sonic telemetry. Lines are inferred tracks between daily locations. Shaded areas denote seagrass meadows. Note differences in scale bars 

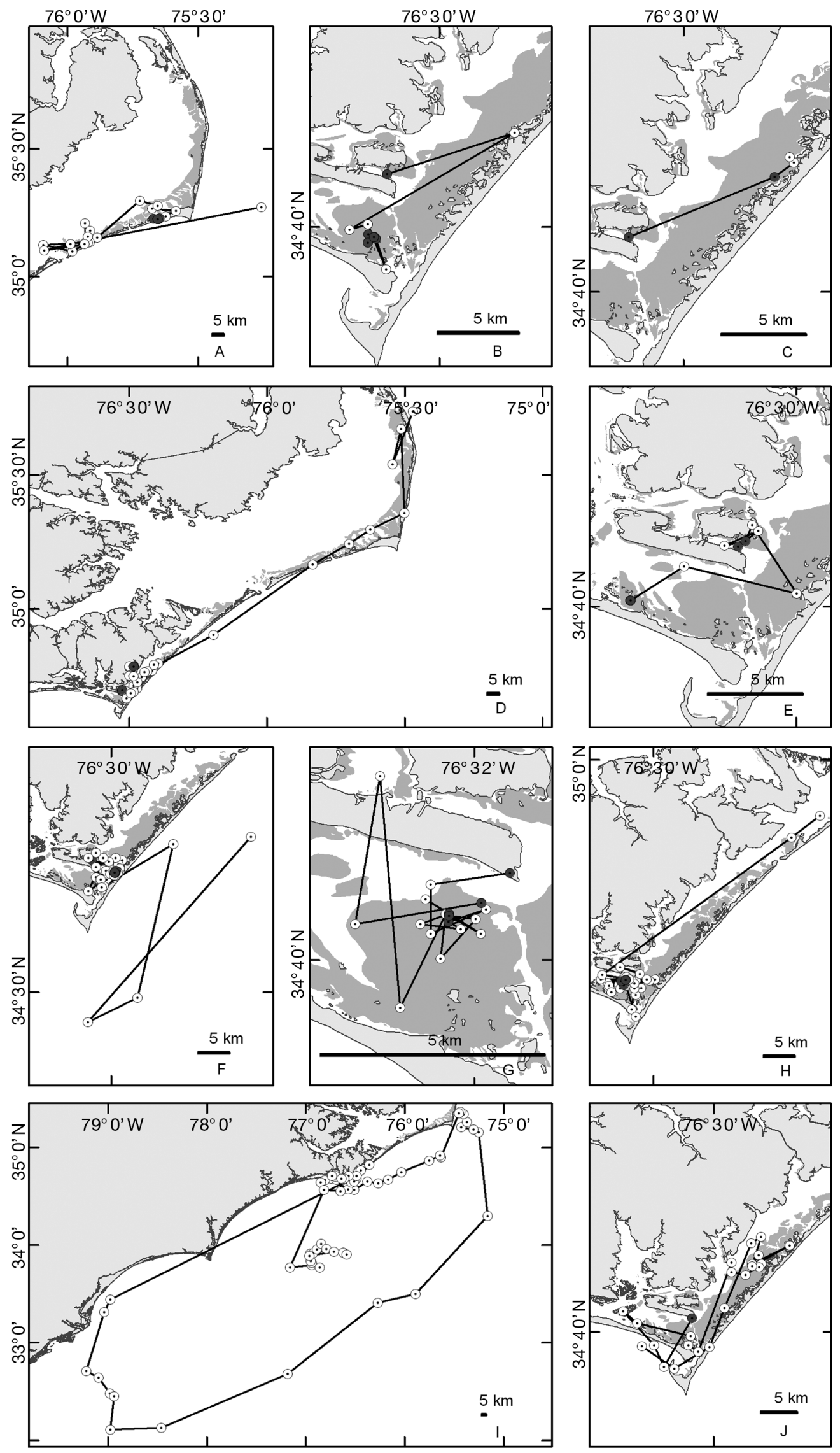


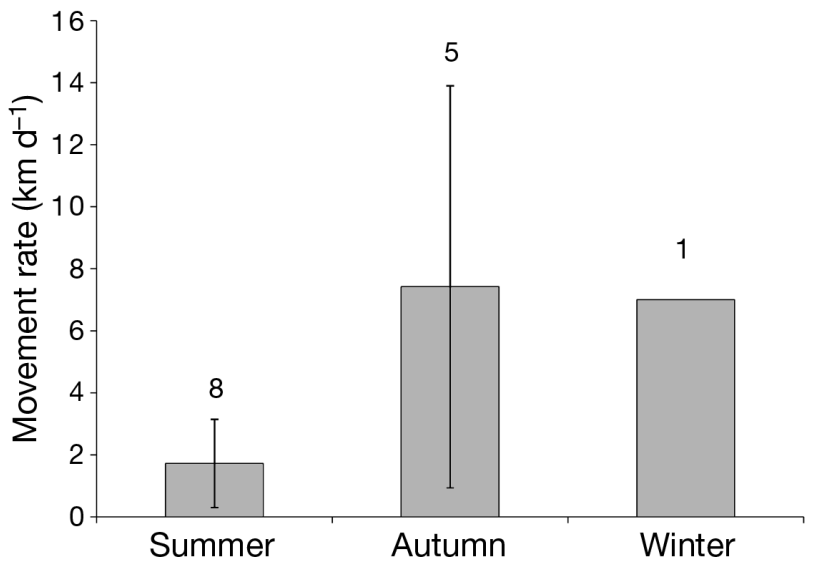

Fig. 3. Chelonia mydas. Mean movement rate $\left(\mathrm{km} \mathrm{d}^{-1}\right)$ of turtles by season based on satellite locations. Error bars are \pm 1 SD. Numbers above bars indicate number of turtles

and resulting in shedding of the transmitters. Five of the turtles were tracked out of the sounds (Fig. 2), but only one of these turtles (Turtle I) was followed for a significant period of time (4 mo) (Fig. 3).

\section{Turtle by-catch in the shallow water fishery}

The DMF observed 522 gill net sets in Core Sound, Back Sound, and Pamlico Sound between May and December 2005 and 2006 (Fig. 4). In the PSGNRA observer coverage was 11.9 and $9.6 \%$ for 2005 and 2006, respectively (Price 2006, 2007a). Four (live) bycaught green turtles were documented in the PSGNRA in 2005 (Price 2006) (Fig. 4) and 5 (2 live, 3 dead) were observed in the PSGNRA in 2006 (Price 2007a) (Fig. 4); all were small juveniles $<36 \mathrm{~cm}$ SCL. The estimated combined numbers of turtles caught in large-mesh gill nets in the PSGNRA was 48 live and 17 dead green turtles during these $2 \mathrm{yr}$ (Price 2006, 2007a). Of the observed green turtle by-catch during this time, $80 \%$ occurred in SGNRA 3 and the remaining $20 \%$ in SGNRA 1 (Fig. 4). Outside the PSGNRA, 1 green turtle was observed dead in large-mesh gear in Back Sound (2005) and 1 green turtle was observed alive in largemesh gear in Pamlico Sound (2006) (Price 2007b) (Fig. 4). Since the initiation of the PSGNRA in 2002, the estimated by-catch based on fishing effort of all sea turtles in large-mesh gill nets in the PSGNRA has declined, except for green turtles (Fig. 5).

We noted 58 large-mesh gill net sets opportunistically while tracking turtles during the summer (Fig. 5). As mentioned above, we found 1 of our tagged turtles in a large-mesh gill net. We also witnessed long haul seine activity on at least 4 occasions, and 1 of our tagged turtles was also re-captured in this gear.

\section{Habitat analyses}

Habitat metrics of green turtles sampled during the summer from satellite and sonic tracking were similar, although satellite-derived locations occurred in slightly deeper water and at greater distances to features (Table 2). In general, turtles occupied mean temperatures between 26 and $28^{\circ} \mathrm{C}$ and water depths $<1 \mathrm{~m}$ (Table 2). Turtles were found close to the shoreline (mean $<1 \mathrm{~km}$ ) and near seagrass meadows (mean $<200 \mathrm{~m}$ ) (Table 2). In total, $94 \%$ of the sonic locations

Table 2. Chelonia mydas. Estuarine green turtle habitat use metrics. Superscript indicates season - S: summer (May to August); A: autumn (September to November); W: winter (December to January). N indicates the number of locations used — mpd: multiple locations per day; bpd: best location per day. 95th percentile density utilization distributions (UD) are reported as seasonal home range areas $(\mathrm{mpd})$. Habitat metric values are means of the bpd $( \pm 1 \mathrm{SD})$. Sat: satellite; Son: sonic

\begin{tabular}{|c|c|c|c|c|c|c|c|c|c|c|c|c|}
\hline \multirow[t]{2}{*}{$\begin{array}{l}\text { Turtle } \\
\text { ID }\end{array}$} & \multicolumn{2}{|c|}{$\begin{array}{c}\mathrm{N} \\
(\mathrm{mpd} / \mathrm{bpd})\end{array}$} & \multicolumn{2}{|c|}{$\begin{array}{l}\text { UD } \\
\left(\mathrm{km}^{2}\right)\end{array}$} & \multicolumn{2}{|c|}{$\begin{array}{l}\text { Temperature } \\
\left({ }^{\circ} \mathrm{C}\right)\end{array}$} & \multicolumn{2}{|c|}{$\begin{array}{l}\text { Depth } \\
(\mathrm{m})\end{array}$} & \multicolumn{2}{|c|}{$\begin{array}{l}\text { Distance to } \\
\text { seagrass }(\mathrm{km})\end{array}$} & \multicolumn{2}{|c|}{$\begin{array}{l}\text { Distance to } \\
\text { shore }(\mathrm{km})\end{array}$} \\
\hline & Sat & Son & Sat & Son & Sat & Son & Sat & Son & Sat & Son & Sat & Son \\
\hline$A^{S}$ & $14 / 7$ & $27 / 8$ & 171.6 & 19.1 & $28(2)$ & $29.6(1.8)$ & $2(1.2)$ & $0.5(0)$ & $1.9(2.4)$ & $0.01(0.04)$ & $4(2.9)$ & 0.09 \\
\hline $\mathrm{A}^{\mathrm{A}}$ & $15 / 6$ & & 106.1 & & 25 (1) & & $2(1.4)$ & & $1.3(1.5)$ & & $1.6(1.5)$ & $(0.04)$ \\
\hline $\mathrm{B}^{\mathrm{S}}$ & $12 / 3$ & $13 / 7$ & 97.6 & 47.4 & $24(3)$ & 26.9 (3) & $0.5(0)$ & $0.5(0)$ & $0.03(0.06)$ & $0.01(0.04)$ & $0.8(0.5)$ & $0.2(0.04)$ \\
\hline $\mathrm{C}^{\mathrm{S}}$ & $8 / 3$ & $8 / 2$ & 60.8 & 52.2 & $24(3)$ & $25.4(4)$ & $0.5(0)$ & $0.5(0)$ & $0.03(0.06)$ & $0(0)$ & $0.3(0.09)$ & $0.7(0.4)$ \\
\hline $\mathrm{D}^{\mathrm{S}}$ & $121 / 25$ & $30 / 4$ & 140.3 & 47.7 & $25(2)$ & $25.6(2.4)$ & $0.5(0.1)$ & $0.5(0)$ & $0.08(0.1)$ & $0.1(0.1)$ & $0.6(0.4)$ & $0.1(0.09)$ \\
\hline $\mathrm{E}^{\mathrm{S}}$ & $35 / 6$ & $24 / 7$ & 71.1 & 53.4 & 25 (1) & $28.2(2.8)$ & $0.6(0.2)$ & $0.5(0)$ & $0.2(0.2)$ & $0(0)$ & $0.3(0.2)$ & $0.2(0.1)$ \\
\hline $\mathrm{F}^{\mathrm{S}}$ & $225 / 40$ & $31 / 11$ & 40.2 & 30.2 & $25(1)$ & $28.3(2.5)$ & $0.5(0.1)$ & $0.5(0)$ & $0.02(0.08)$ & $0(0)$ & $0.3(0.3)$ & $0.2(0)$ \\
\hline $\mathrm{G}^{\mathrm{S}}$ & $94 / 15$ & $18 / 4$ & 45.2 & 33.7 & $26(1)$ & $28.7(0.8)$ & $1(0.1)$ & $0.5(0)$ & $0.06(0.1)$ & $0(0)$ & $1(0.5)$ & $1.2(0.3)$ \\
\hline $\mathrm{H}^{\mathrm{S}}$ & $89 / 15$ & $12 / 4$ & 49.8 & 33.9 & $26(1)$ & $26.7(0.8)$ & $1(0.9)$ & $0.5(0)$ & $0.08(0.1)$ & $0.05(0.1)$ & $0.1(0.5)$ & $1(0.2)$ \\
\hline $\mathrm{H}^{\mathrm{A}}$ & $55 / 20$ & & 94.8 & & $22(3)$ & & $1(0.8)$ & & $0.2(0.3)$ & & $0.4(0.4)$ & \\
\hline $\mathrm{I}^{\mathrm{W}}$ & $38 / 12$ & & 171.8 & & $13(1)$ & & $1.5(2.4)$ & & $0.4(0.5)$ & & $0.5(0.4)$ & \\
\hline $\mathrm{J}^{\mathrm{A}}$ & $59 / 18$ & & 174.7 & & $18(4)$ & & $1.1(2)$ & & $0.3(0.3)$ & & $0.8(0.5)$ & \\
\hline Means & $75 / 14$ & $21 / 6$ & 84.6 & 39.7 & $26(1.5)$ & $27.8(2.5)$ & $0.7(0.6)$ & $0.5(0)$ & $0.2(0.7)$ & $0.02(0.05)$ & $0.8(1.2)$ & $0.4(0.4)$ \\
\hline
\end{tabular}




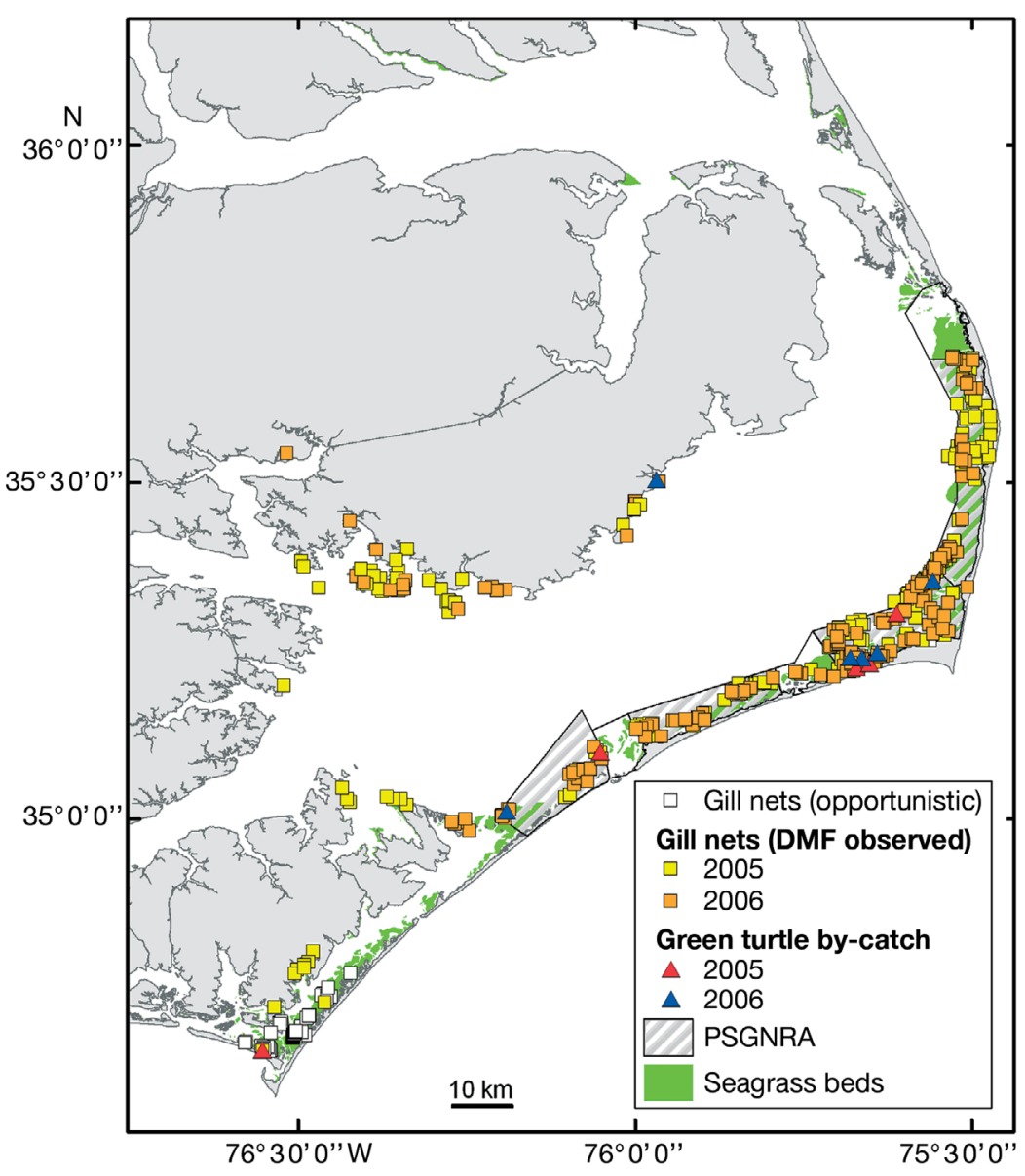

Fig. 4. Locations of large-mesh gill nets observed opportunistically during our tracking surveys (white squares) or by the Division of Marine Fisheries (DMF; yellow and orange squares) and green turtle by-catch observed by DMF (red and blue triangles) between May and December of 2005 and 2006. PSGNRA: Pamlico Sound Gill Net Restricted Area

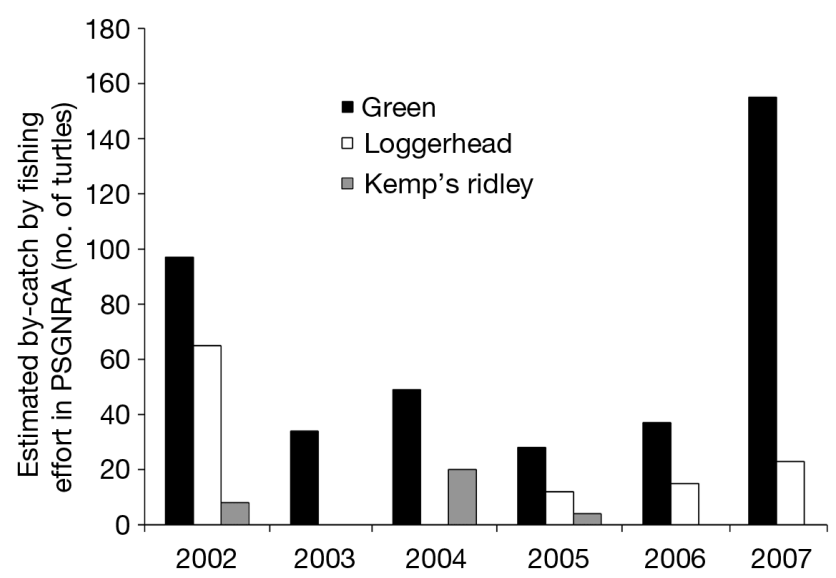

Fig. 5. Chelonia mydas, Caretta caretta and Lepidochelys kempii. Estimated by-catch by fishing effort (length of net $[\mathrm{m}] \times$ soak time $[\mathrm{d}]$ ) of sea turtles in the PSGNRA (Pamlico Sound Gill Net Restricted Area) from 2002 to 2007. Data compiled from Gearhart (2003) and Price $(2004,2005,2006$, 2007a, 2008) occurred directly in seagrass (direct observation), while $67 \%$ of the satellite locations fell within seagrass (as determined by GIS).

Similarly, large-mesh gill nets occurred at mean depths $<1 \mathrm{~m}$ and within $500 \mathrm{~m}$ of seagrass meadows (Table 3). Nets observed by DMF were found at a greater range of distances from shore (mean $2.3 \mathrm{~km}$ ) than those we found serendipitously while searching for turtles (mean <1 km) (Table 3). These latter nets were most often placed on the barrier island side of the sounds and across small tidal creeks or in front of marsh islands and were unattended by fishers.

The available habitat at the study site scale was determined through sampling 500 randomized point locations, i.e. approximately 3 times the total number of daily turtle locations. Mean $( \pm 1 \mathrm{SD})$ values are reported in Table 3. Use/ availability ratios indicated that, during summer, the locations of green turtles differed from random locations at both the second (study site) and third (UD) order selection scales $\left(F_{3,5}=61.95, \mathrm{p}<\right.$ $0.001 ; F_{3,5}=10.94, \mathrm{p}<0.05$, respectively). There was no significant difference between turtles and random points with regard to water depth $\left(\rho_{\text {depth }}=-0.14 \pm\right.$ $0.12($ mean $\left.\pm 1 \mathrm{SE}), t_{7}=-1.13, \mathrm{p}=0.297\right)$, but turtles were found closer to seagrass and closer to shore than expected ( $\rho_{\text {seagrass }}$ $=-0.77 \pm 0.15, t_{7}=-5.04, \mathrm{p}=0.001 ; \rho_{\text {shore }}$ $\left.=-0.50 \pm 0.13, t_{7}=-3.74, \mathrm{p}=0.007\right)$. Within the UDs of the turtles, there was no difference between turtles and random points with regard to either water depth or distance to shore $\left(\rho_{\text {depth }}=-0.14 \pm 0.07\right.$, $t_{7}=-2.08, \mathrm{p}=0.076, \rho_{\text {shore }}=0.008 \pm 0.22, t_{7}=0.04$, $\mathrm{p}=0.972)$, but turtles were closer to seagrass than expected $\left(\rho_{\text {seagrass }}=-0.57 \pm 0.09, t_{7}=-6.17, \mathrm{p}<0.001\right)$.

Table 3. Estuarine gill net fisher's habitat use and available habitat (random) metrics. Superscript indicates seasonS: summer (May to August); A: autumn (September to November). Values are means $( \pm 1 \mathrm{SD})$

\begin{tabular}{|lccc|}
\hline $\begin{array}{l}\text { Locations in } \\
\text { study sites }\end{array}$ & $\begin{array}{c}\text { Depth } \\
(\mathrm{m})\end{array}$ & $\begin{array}{c}\text { Distance to } \\
\text { seagrass }(\mathrm{km})\end{array}$ & $\begin{array}{c}\text { Distance to } \\
\text { shore }(\mathrm{km})\end{array}$ \\
\hline $\begin{array}{l}\text { DMF observed } \\
\text { large-mesh gill nets }\end{array}$ & $0.6(0.3)$ & $0.5(1.5)$ & $2.3(1.9)$ \\
$\begin{array}{l}\text { Opportunistic } \\
\text { large-mesh gill nets }\end{array}$ & $0.5(0.2)$ & $0.01(0.04)$ & $0.7(0.9)$ \\
Random & $0.8(0.7)$ & $0.7(1)$ & $1.4(1.5)$ \\
\hline
\end{tabular}


We used habitat selection indices (i.e. use - availability) to identify areas in which one would expect to find green turtles and/or large-mesh gill nets within the shallow waters of North Carolina estuaries. Within our study site, we found that turtles preferred water depths $<1 \mathrm{~m}$, distances from shore between 0.1 and $2 \mathrm{~km}$, and proximities to seagrass $<0.5 \mathrm{~km}$ based on the availability of habitat (Fig. 6). Turtles $\mathrm{G}$ and H were exceptions to this pattern, preferring depths between 1 and $2 \mathrm{~m}$ and areas up to $2 \mathrm{~km}$ from shore in Back Sound (Fig. 2). Turtle A was found on 3 occasions in deep water far from both the shore and seagrass, as it moved between 2 foraging sites in Pamlico Sound (Fig. 2). Habitat preferences were reasonably similar within the animals' UDs: all turtles preferred depths $<1 \mathrm{~m}$ and within $0.1 \mathrm{~km}$ of seagrass beds (Fig. 6). However, turtles were split with respect to distance to shore: Turtles A, B, C, $\mathrm{E}$, and $\mathrm{F}$ preferred areas $<1 \mathrm{~km}$ from shore, while Turtles D, G, and $\mathrm{H}$ preferred areas 1 to $2 \mathrm{~km}$ from shore (Fig. 6).

Gill nets were preferentially set in depths $<1 \mathrm{~m}$, distances from shore between 4 and $7 \mathrm{~km}$, and within $0.1 \mathrm{~km}$, from 5.0 to $6.5 \mathrm{~km}$, and $>7 \mathrm{~km}$ from seagrass based on availability of habitat within the study area (Fig. 6) although the preference for within $0.1 \mathrm{~km}$ of seagrass is much greater than the marginal preferences shown for 5.0 to 6.5 and $>7 \mathrm{~km}$. We combined the ranges of values for preferred habitat above for both turtles and gill net fishers (Fig. 7). The areas of potential conflict due to overlap of preferred habitat matched well with the records of observed green turtle by-catch over the last 8 yr (Fig. 7).
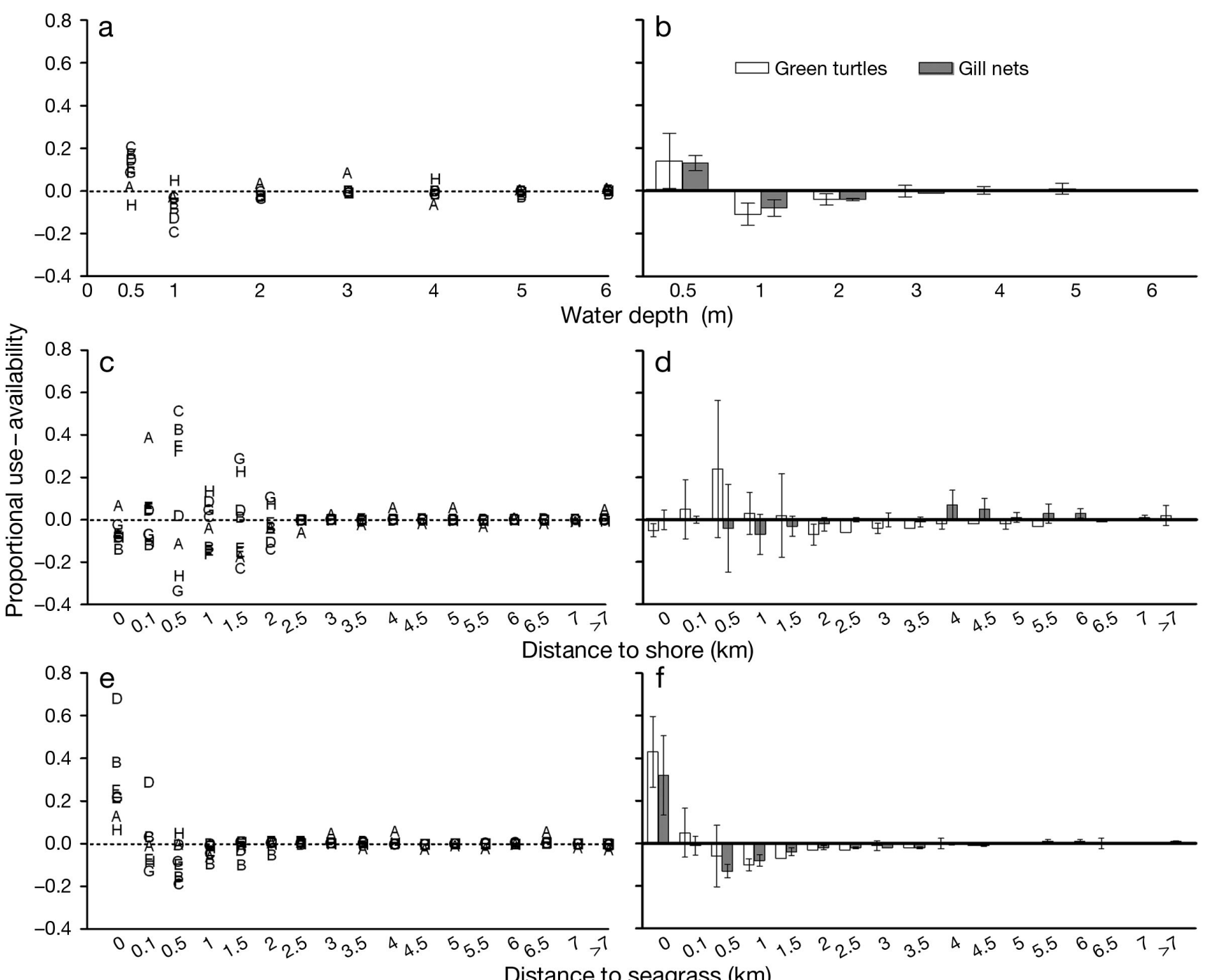

Fig. 6. Summertime habitat selection for green turtles and large-mesh gill net flounder fishery with respect to (a,b) water depth, $(c, d)$ distance to shore, and $(e, f)$ distance to seagrass. Positive values indicate preference (i.e. use > availability). (a,c,e) analysis within the turtles' utilization distributions, where letters identify the individual. (b,d,f) Mean $( \pm 1$ SD) values based on analysis at the scale of the study area 


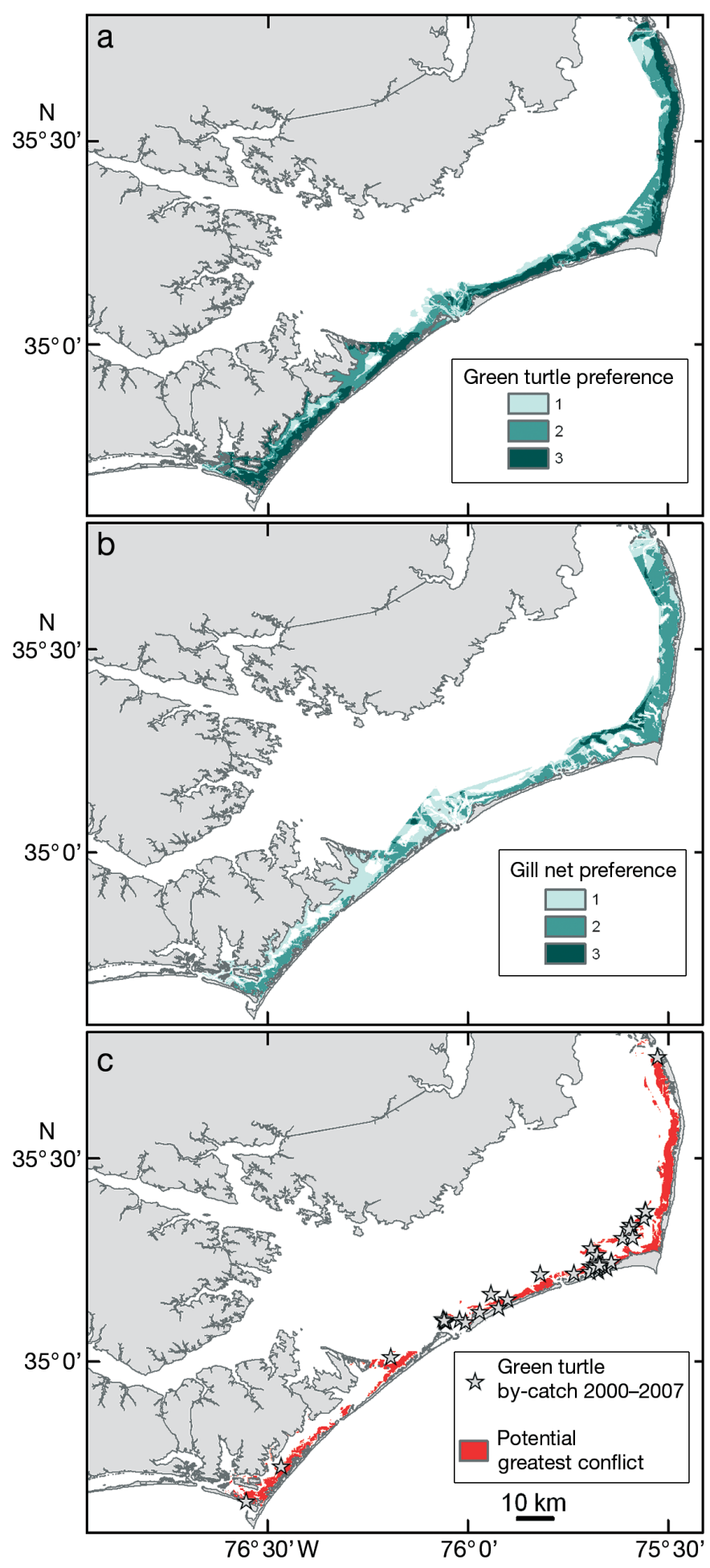

Fig. 7. Habitats preferred by (a) green turtles and (b) gill net fishers. Values indicate areas where a number of the habitat parameters were preferred (see Fig. 6), where 3 is the highest combined preference ranking. (c) Spatial region where habitat use may conflict most between fishers and turtles. (하) : locations of green sea turtle by-catch in large-mesh gill nets documented by the Division of Marine Fisheries between 2000 and 2007

\section{DISCUSSION}

Individual juvenile green turtles exhibited strong site fidelity during the summer months and were closely tied to seagrass habitat. The habitat selection of turtles was similar at 2 scales of availability, likely due, in part at least, to the shallow water nature of our study area. The summer home ranges of green turtles were extremely small, and individual turtles could be found each day in the same bay or tidal creek - a pattern that is consistent with other studies of green turtles in the southeastern USA (Mendonça 1983). Such fidelity is masked, to some degree, in location error from satellite-derived positional estimates, but our sonic tracking allowed us to document the exact positions of individual turtles. In her Florida lagoonal work, Mendonça (1983) reported that individuals returned to sleeping sites within $3 \mathrm{~m}$ of their location on the previous night. We did not conduct nocturnal tracking, but our work suggests that animals show similar fidelity especially to tidal creeks along the barrier islands and marsh islands.

Green turtles occurred most frequently at the edge of seagrass beds and often retreated into the beds when disturbed. Seven of 10 turtles settled into tidal creeks or near marsh islands. These areas are sheltered, calm, shallow, and offer refuge from large predators (i.e. sharks) and boats. When turtles were found farther from shore they were usually near persistent sandbars or marsh islands; perhaps any type of structure, submerged or emergent, may be equally appealing to small green turtles.

Similar to the results of Mendonça (1983), the turtles in our study moved very little during the warm months. Most individuals returned to a particular foraging area even after short forays. Our findings, therefore, suggest that incidental capture of green turtles during summer is mediated by gear deployed in their foraging or sleeping site. We were able to track each turtle for only a few weeks, so it is unclear how long this site fidelity lasts within a season, or whether disturbance may cause a turtle to abandon its preferred habitat.

Proximity to seagrass was clearly important for the green turtles in our study. Of our sonic observations, $94 \%$ were made directly in seagrass. Only $67 \%$ of the satellite records fell in seagrass, but the location error associated with this method likely resulted in an underestimate of the time spent in this patchy habitat. Despite their strong site fidelity and association with seagrass, we did not observe the cropped 'lawns' described in Bjorndal (1980). Small round bare patches were occasionally observed in the seagrass, but were more likely the result of fish grazing, in which the whole plant is torn out of the ground, than clipping by green turtles. The UDs of turtles in our study were 
much larger than Bjorndal's study site $\left(0.03 \mathrm{~km}^{2}\right)$ and, as mentioned above, our monitoring lasted only a few weeks at any given site. Therefore, we may not have been able to capture this behavior, or perhaps the turtles in our study selectively foraged on new growth throughout the seagrass meadows, rather than maintaining individual gardens.

In total, $70 \%$ of the observed gill net sets occurred within seagrass, suggesting that these areas are important fishing grounds. Fish assemblages are more abundant and diverse in seagrass beds than in adjacent sandy areas (Joseph et al. 2006). Distribution of flounders as estuarine predators, for example, is likely to be greater where prey resources are most profitable (MacArthur \& Pianka 1966, Wright et al. 1993, Harter \& Heck 2006). Seagrass is restricted to shallow areas and, as expected, both turtles and nets were mainly located in water $<1 \mathrm{~m}$ deep. However, not all shallow water contains seagrass. So, it is the combination of these 2 habitat parameters that is important for the co-occurrence of turtles and nets. Distance from the shore was highly variable among gill net sets. Fishers often placed their nets perpendicular to submerged shoals or near marsh islands, as these features serve as natural leads which direct fish towards their nets. A notable local example is the long series of shoals that run along the inside of the Outer Banks behind Hatteras and Ocracoke, representing a highly popular fishing area in the PSGNRA (SGNRA 2 and SGNRA 3) (McClellan et al. 2009).

Disturbance, whether anthropogenic (boats, incidental capture) or natural (interspecific interactions, weather), may also play a role in the encounters between turtles and fishing gear. Despite 2 intensive periods of field observations, lasting for a total of $8 \mathrm{mo}$ over $2 \mathrm{yr}$, we made very few sightings of non-telemetered turtles. We observed loggerheads and diamondback terrapins Malaclemys terrapin, but no green turtles other than those which we had tagged. Studies examining the catch rate of sea turtles in these waters show that green turtles are much less common than loggerheads (Sasso et al. 2007). During our tracking efforts, we found green turtles to be extremely wary of boats, and our tagged turtles darted away when approached. Their surfacings were quick and inconspicuous. Balazs et al. (1987), Renaud et al. (1995), and Seminoff et al. (2002) also reported that green turtles may alter their behavior to avoid human activity. Thus, their wariness and surfacing behavior, combined with their small size, appears to be responsible for our lack of green turtle sightings. We hypothesize that disturbance leads turtles to move and that the distance they move is a function of the degree of disturbance. Minor disturbances may result in temporary retreats into seagrass beds, as was the case when a green turtle was too closely investigated by a loggerhead turtle.
We found that movement rates increased predictably during the autumn, consistent with the onset of migration triggered by falling temperatures (Mendonça 1983). Even while making longer distance movements in our study area (i.e. $7 \mathrm{~km} \mathrm{~d}^{-1}$ ), green turtles traveled through areas of seagrass. Therefore, during estuarine migration, nets set in close proximity to seagrass meadows are likely to be encountered by green turtles. Because the turtles are covering greater distances, the rate of encounter with gill nets increases as they move through a gauntlet of fishing gear.

The behaviors of Turtles E and B suggest that green turtles may conserve energy by drifting in and out of creeks with the tide. Turtle B was tracked in an area where the current flow was strong, and this individual moved around the marsh island so as not to be transported away from the area, whereas Turtle B moved back and forth in a creek with the tide. These findings are similar to those of Byles (1988) and Mansfield (2006) who documented tidal-related movements of loggerhead and Kemp's ridley turtles in Chesapeake Bay. Therefore, tidal cycle may be an important factor in the probability of encountering nets set in a foraging site. Fishers often set nets overnight and over tidal cycles. Flounder have been shown to move in and out of creeks with the tide during the night (Szedlmayer \& Able 1993, Rountree \& Able 1997).

While the management of the gill net fishery in Pamlico Sound is considered successful overall, it has not reduced the number of interactions between green turtles and gill nets in shallow water seagrass habitats that are still open to fishing. Spatial and temporal overlap in itself does not necessarily lead to entanglement, as evidenced by the frequency with which we witnessed fishing activity in locations where we tracked turtles. By-catch, however, cannot occur without spatial and temporal overlap. The more gill nets there are in an area, the greater the chance of a turtle encountering a net. We estimate that $32 \%$ of the PSGNRA is preferred green sea turtle habitat. When observed by-catches were superimposed on the overlap of preferred turtle habitat and preferred fishing areas, there was an almost perfect match (Fig. 7). The permitted by-catch authorized by NMFS to the PSGNRA fishery implies by definition that the current level of by-catch is sustainable to the green turtle population. A full assessment of the impact of these by-catches has yet to be conducted, however.

In addition to the high degree of overlap between green turtles and gill nets, one of the most striking results of our study was the high rate of interactions between green turtles and other fisheries in the sounds of North Carolina. All turtles were initially caught in pound nets, long haul seines, or by hook and line. At least 3 turtles were caught a second time in a large- 
mesh gill net, long haul seine, or pound net. Two of these turtles may have been caught a third time, based on an unusual series of high quality satellite uplinks. Fortunately, most of these interactions were non-lethal. In fact, the vast majority of green turtles captured in North Carolina fisheries and observed by state or federal observers are released alive (Epperly et al. 2007, Price 2007b), likely due to the ability of turtles to reach the surface and breathe. To our knowledge, this is the first paper to describe multiple incidental capture rates for individuals in different gears in this region.

The potential for multiple live captures raises the question of capture stress and delayed mortality. Few studies have been conducted on post-release mortality of sea turtles. Harms et al. (2003) demonstrated that incidental capture resulted in adverse changes in loggerhead turtle blood chemistry and that these changes were greater in animals that had been forcibly submerged. Turtles can drown during forced submergences in as little as 10 min (Sasso \& Epperly 2006), and repeated capture may reduce submergence endurance (Lutcavage \& Lutz 1991). High survival rates $(>0.8)$ have been reported for sea turtles hooked in longline gear (Swimmer et al. 2006, Sasso \& Epperly 2007), but questions still remain as to the sub-lethal effects of incidental capture and the potential for increased susceptibility to other threats, such as boat strikes, predators, cold stunning, or infection postrelease. Recapture rates of green turtles (based on flipper and PIT tags) are low in pound nets (Epperly et al. 2007) and have not been observed in gill nets in the PSGNRA (B. Price pers. comm.), although gill net fishers in the PSGNRA are instructed to escort by-caught turtles to inlets during the autumn. Therefore, it is uncertain whether re-captures are low because disturbed turtles leave the area, whether their survivorship is low, or whether they leave the estuary after being released near inlets. Research is currently underway on the post-release survival of green and Kemp's ridley turtles in North Carolina; preliminary data show increased stress levels of animals entangled in large-mesh nets in $4 \mathrm{~h}$ or less (Snoddy 2009), similar to the findings of Harms et al. (2003) for trawls and pound nets. Preliminary research (Snoddy 2009) suggests that post-release mortality occurs in $<1$ mo as a result of physiological stress (specifically, a Kemp's ridley mortality $1 \mathrm{wk}$ post-release) and that mortality rates may be as high as 7 to $29 \%$. As noted above, we documented a post-release mortality within 1 mo of capture in a shallow water gill net. No other studies have been published on the post-release mortality of turtles in gill nets.

Current management practices in the PSGNRA restrict the use of flounder gill nets to the shallow water fishing grounds along the margins of Pamlico
Sound. This restriction has the intended effect of greatly reducing the by-catch of (mostly) loggerhead turtles, but concentrates fishing effort into shallow waters where green turtles are captured frequently. DMF now monitors the shallow-water fishery in Pamlico Sound with a dedicated observer program to ensure that by-catch does not exceed permitted removal levels. In fact, the shallow water fishery was closed 1 mo early in 2007 when green turtle takes surpassed the allowable threshold (Proclamation M-192007, November 13, 2007; North Carolina Division of Marine Fisheries 2005-2007). Our research indicates that by-catches of green turtles also occur in gill nets (and other fishing gears) in the shallow water habitats in Back and Core Sounds, outside the current PSGNRA. We conclude that similar conservation measures, including dedicated observer programs, are required in these shallow habitats used intensively by both green turtles and commercial fishers. Without such measures it will not be possible to fully assess the extent of green turtle by-catch in North Carolina's estuarine fisheries. We also recommend that further research be conducted into the post-release condition of by-caught turtles to allow estimation of total mortality. The potential for adverse ecological effects in these shallow water areas is exacerbated by the very small home ranges exhibited by green turtles during the foraging season.

Acknowledgements. This research was the product of extensive collaboration between federal, state, and academic researchers and commercial fishermen. Funding was provided by North Carolina Sea Grant Fisheries Research Grant 05-FEG-02. Research was authorized under NMFS scientific permit \#1260 and Duke University's Animal Care and Use Protocol A126-05-04. We thank the fishers who participated in this study and helped with sea turtle collection. B. Price from DMF provided the fisheries and by-catch data used in this study. A. Uhrin from NOS shared the seagrass polygons. J. McNeill, L. Avens, L. Goshe, and A. Goodman from the NMFS Beaufort lab were invaluable in their logistical assistance and for reports of re-captured animals and tags. We thank S. Epperly at the NMFS Miami lab for her support and encouragement in pursuing this study. We are indebted to $\mathrm{M}$. Godfrey from the North Carolina Wildlife Resources Commission for providing access to our first green turtle in this project. The National Parks Service provided boat storage and launching facilities. P. Gillikin, D. Waples, J. Wicker, M. McClellan, C. Good, C. Hudson, M. Wise, L. Williams, and R. Spears participated in the many hours of turtle tracking. J. Roberts provided assistance with GIS aspects of this project. We also thank B. Godley and 3 anonymous reviewers for comments that greatly improved this manuscript.

\section{LITERATURE CITED}

Austin D, McMillan JI, Bowen WD (2003) A three-stage algorithm for filtering erroneous Argos satellite locations. Mar Mamm Sci 19:371-383 
Balazs GH, Forsyth RG, Kam AKH (1987) Preliminary assessment of habitat utilization by Hawaiian green turtles in their resident foraging pastures. NOAA Tech Memo NMFS-SWFC-71

Bartol SM, Musick JA (2003) Sensory biology of sea turtles. In: Lutz PL, Musick JA, Wyneken J (eds) The biology of sea turtles, Vol II. CRC Press, Boca Raton, FL, p 79-102

Beyer H (2004) Hawth's analysis tools for ArcGIS 3.23

Bjorndal KA (1980) Nutrition and grazing behavior of the green turtle Chelonia mydas. Mar Biol 56:147-154

Bjorndal KA (1997) Foraging ecology and nutrition of sea turtles. In: Lutz PL, Musick JA, Wyneken J (eds) The biology of sea turtles, Vol II. CRC Press, Boca Raton, FL, p 199-231

Byles RA (1988) Behavior and ecology of sea turtles from Chesapeake Bay, Virginia. PhD dissertation, College of William and Mary, Williamsburg, VA

Conner LM, Plowman BW (2001) Using Euclidean distances to assess nonrandom habitat use. In: Millspaugh JJ, Marzluff JM (eds) Radio tracking and animal populations. Academic Press, San Diego, CA, p 275-290

> Crouse DT, Crowder LB, Caswell H (1987) A stage-based population model for loggerhead sea turtles and implications for conservation. Ecology 68:1412-1423

de Solla SR, Bonduriansky R, Brooks RJ (1999) Eliminating autocorrelation reduces biological relevance of home range estimates. J Anim Ecol 68:221-234

Epperly SP, Braun J, Veishlow A (1995) Sea turtles in North Carolina waters. Conserv Biol 9:384-394

Epperly SP, Braun-McNeill J, Richards PM (2007) Trends in catch rates of sea turtles in North Carolina, USA. Endang Species Res 3:283-293

ESRI (Environmental Systems Research Institute) (1999) ArcView GIS 3.2 software. ESRI, Redmond, WA

ESRI (Environmental Systems Research Institute) (2006) ArcGIS 9.2. software. ESRI, Redmond, WA

Ferguson RL, Korfmacher K (1997) Remote sensing and GIS analysis of seagrass meadows in North Carolina, USA. Aquat Bot 58:241-258

Ferguson RL, Thayer GW, Rice TR (1980) Functional adaptation of marine organisms. In: Vernberg FJ, Vernberg W (eds) Marine primary producers. Academic Press, New York, p 9-69

Ferguson RL, Wood LL, Graham DB (1993) Monitoring spatial change in seagrass habitat with aerial photography. Photogramm Eng Remote Sensing 59:1033-1038

Fonseca MS, Zieman JC, Thayer GW, Fisher JS (1983) The role of current velocity in structuring eelgrass (Zostera marina L.) meadows. Estuar Coast Shelf Sci 17:367-380

Gearhart J (2003) Sea turtle bycatch monitoring of the 2002 fall flounder gillnet fishery of southeastern Pamlico Sound, North Carolina. North Carolina Department of Environment and Natural Resources, Division of Marine Fisheries; Morehead City, NC

> Harms CA, Mallo KM, Ross PM, Segars A (2003) Venous blood gases and lactates of wild loggerhead sea turtles (Caretta caretta) following two capture techniques. J Wildl Dis 39:366-374

> Harter SL, Heck KL Jr (2006) Growth rates of juvenile pinfish (Lagodon rhomboides): effects of habitat and predation risk. Estuar Coast 29:318-327

Hays GC, Åkesson S, Godley BJ, Luschi P, Santidrian P (2001) The implications of location accuracy for the interpretation of satellite-tracking data. Anim Behav 61:1035-1040

Hooge PN, Eichenlaub B (2000) Animal movement extension to ArcView 2.0. USGS Alaska Science Center, Anchorage, AK

> Johnson DH (1980) The comparison of usage and availability measurements for evaluating resource preference. Ecology 61:65-71
Joseph V, Locke A, Godin JJ (2006) Spatial distribution of fishes and decapods in eelgrass (Zostera marina L.) and sandy habitats of a New Brunswick estuary, eastern Canada. Aquat Ecol 40:111-123

Kernohan BJ, Gitzen RA, Millspaugh JJ (2001) Analysis of animal space use and movements. In: Millspaugh JJ, Marzluff JM (eds) Radiotracking and animal populations. Academic Press, San Diego, CA, p 126-168

Laver PN, Kelly MJ (2008) A critical review of home range studies. J Wildl Manag 72:290-298

> Lewison RL, Freeman SA, Crowder LB (2004) Quantifying the effects of fisheries on threatened species: the impact of pelagic longlines on loggerhead and leatherback sea turtles. Ecol Lett 7:221-231

Lutcavage ME, Lutz PL (1991) Voluntary diving metabolism and ventilation in the loggerhead sea turtle. J Exp Mar Biol Ecol 147:287-296

> MacArthur RH, Pianka ER (1966) On optimal use of a patchy environment. Am Nat 100:603-609

Mansfield KL (2006) Sources of mortality, movements and behavior of sea turtles in Virginia. PhD dissertation, College of William and Mary, Williamsburg, VA

> McClellan CM, Read AJ (2007) Complexity and variation in loggerhead sea turtle life history. Biol Lett 3: 592-594

McClellan CM, Read AJ, Price BA, Cluse WM, Godfrey MH (2009) Using telemetry to mitigate the by-catch of longlived marine vertebrates. Ecol Appl (in press)

> McConnell BJ, Chambers JC, Fedak MA (1992) Foraging ecology of southern elephant seals in relation to the bathymetry and productivity of the Southern Ocean. Antarct Sci 4:393-398

Mendonça MT (1983) Movements and feeding ecology of immature green turtles (Chelonia mydas) in a Florida Lagoon. Copeia 1983:1013-1023

NMFS (National Marine Fisheries Service) (2002) Sea turtle conservation; restrictions to fishing activities. Federal Register 67:56931-56934

NMFS SEFSC (National Marine Fisheries Service Southeast Fisheries Science Center) (2008) Sea turtle research techniques manual. NMFS-SEFSC-579. NOAA Tech MemoNOAA-NOS Special Projects Office (1998) Estuarine Bathymetry. 30 meter resolution Digital Elevation Model (DEM). Available online: http://estuarinebathymetry.noaa. gov/

North Carolina Division of Marine Fisheries (2005 - 2007) Proclamations M-8-2005, M-9-2006, M-7-2007. Accessed 23 Sept. www.ncfisheries.net/procs/index.html/

Peckham SH, Diaz DM, Walli A, Ruiz G, Crowder LB, Nichols WJ (2007) Small-scale fisheries bycatch jeopardizes endangered Pacific loggerhead turtles. PLoS One 2:e1041

Price B (2004) Sea turtle bycatch monitoring of the 2003 fall flounder gillnet fishery of southeastern Pamlico Sound, North Carolina. North Carolina Department of Environment and Natural Resources, Division of Marine Fisheries, Morehead City, NC

Price B (2005) Sea turtle bycatch monitoring of the 2004 fall flounder gillnet fishery of southeastern Pamlico Sound, North Carolina.North Carolina Department of Environment and Natural Resources, Division of Marine Fisheries, Morehead City, NC

Price B (2006) Sea turtle bycatch monitoring of the 2005 fall flounder gillnet fisheries of southeastern Pamlico Sound, North Carolina.North Carolina Department of Environment and Natural Resources, Division of Marine Fisheries, Morehead City, NC 
Price B (2007a) Sea turtle bycatch monitoring of the 2006 fall flounder gillnet fisheries of southeastern Pamlico Sound, North Carolina. Completion Report for Activities Under ESA Section 10 Incidental Take Permit \# 1528. North Carolina Department of Environment and Natural Resources, Division of Marine Fisheries, Morehead City, $\mathrm{NC}$

Price B (2007b) Estuarine commercial fishery observer program in North Carolina. Report to US Fish and Wildlife Service. Grant No. F-83-R. North Carolina Department of Environment and Natural Resources, Division of Marine Fisheries, Morehead City, NC

Price B (2008) Sea turtle bycatch monitoring of the 2007 fall flounder gillnet fisheries of southeastern Pamlico Sound, North Carolina. Completion Report for Activities Under ESA Section 10 Incidental Take Permit \# 1528. North Carolina Department of Environment and Natural Resources, Division of Marine Fisheries, Morehead City, NC

Renaud ML, Carpenter JA, Williams JA, Manzella-Tirpapak SA (1995) Movements and submergence patterns of loggerhead turtles (Caretta caretta) in the Gulf of Mexico determined through satellite telemetry. Bull Mar Sci 55: $1-5$

Roberts JJ, Best BD, Dunn DC, Treml EA, Halpin PN (2009) Marine geospatial ecology tools: an integrated framework for ecological geoprocessing with ArcGIS, Python, R, MATLAB, and C++. Available online: http://mgel.env. duke.edu/tools

Rountree RA, Able KW (1997) Nocturnal fish use of New Jersey marsh creek and adjacent bay shoal habitats. Estuar Coast Shelf Sci 44:703-711

Santora C (2003) Management of turtle bycatch: can endangered species be protected while minimizing socioeconomic impacts? Coast Manag 31:423-434

SAS Institute (2003) SAS 9.1 software. SAS Institute, Cary, NC

Sasso CR, Epperly SP (2006) Seasonal sea turtle mortality risk from forced submergence in bottom trawls. Fish Res 81: 86-88

Sasso CR, Epperly SP (2007) Survival of pelagic juvenile loggerhead turtles in the open ocean. J Wildl Manag 71: 1830-1835

Sasso CR, Braun-McNeill J, Avens L, Epperly SP (2007) Summer abundance estimates of Caretta caretta (loggerhead turtles) in Core Sound, NC. Southeast Nat 6:365-369

Editorial responsibility: Brendan Godley,

University of Exeter, Cornwall Campus, UK
Sea Turtle Advisory Committee (2006) Sea turtle interactions with North Carolina fisheries. Review and recommendations to the North Carolina Marine Fisheries Commission. North Carolina Division of Marine Fisheries. Morehead City, NC

Seminoff JA, Resendiz A, Nichols WJ (2002) Home range of green turtles Chelonia mydas at a coastal foraging area in the Gulf of California, Mexico. Mar Ecol Prog Ser 242: 253-265

Silverman BW (1986) Density estimation for statistics and data analysis. Chapman \& Hall, London

Snoddy JE (2009) Physiological status and post-release mortality of sea turtles from gilnets in the lower Cape Fear River, North Carolina. Masters thesis, University of North Caronlia, Willmington, NC

Steve C, Gearhart J, Borggaard D, Sabo L, Hohn A (2001) Characterization of North Carolina commercial fisheries with occasional interactions with marine mammals. NOAA Tech Memo NMFS-SEFSC 458:5-12

> Swimmer Y, Arauz R, McCracken M, McNaughton L and others (2006) Diving behavior and delayed mortality of olive ridley sea turtles Lepidochelys olivacea after their release from longline fishing gear. Mar Ecol Prog Ser 323:253-261

Szedlmayer ST, Able KW (1993) Ultrasonic telemetry of age-0 summer flounder, Paralichthys dentatus, movements in a southern New Jersey estuary. Copeia 1993:728-736

Thayer GW, Kenworth WJ, Fonseca MS (1984) The ecology of eelgrass meadows of the Atlantic coast: a community profile. FWS/OBS-84/02, US Fish and Wildlife Service, Washington, DC

- Vincent C, McConnell BJ, Ridoux V, Fedak M (2002) Assessment of Argos location accuracy from satellite tags deployed on captive gray seals. Mar Mamm Sci 18:156-166

Worton BJ (1989) Kernel methods for estimating the utilization distribution in home-range studies. Ecology 70 : 164-168

- Wright RA, Crowder LB, Martin TM (1993) The effects of predation on the survival and size-distribution of estuarine fishes: an experimental approach. Environ Biol Fishes 36: 291-300

Young NM (2001) The conservation of marine mammals using a multi-party approach: an evaluation of the take reduction team process. Ocean Coast Law J 6:293-346

Submitted: September 29, 2008; Accepted: March 12, 2009 Proofs received from author(s): June 5, 2009 